\title{
Systematic review and meta-analysis to determine the associations between glycaemic index and load on markers of cardiovascular disease
}

\author{
C. E. L. Evans ${ }^{1}$, D. E. Threapleton ${ }^{1}$, C. L. Cleghorn ${ }^{1}$, C. Nykjaer $^{1}$, D. C. Greenwood ${ }^{2}$ \\ and V. J. Burley ${ }^{1}$ \\ ${ }^{1}$ School of Food Science and Nutrition, University of Leeds, LS2 9JT and ${ }^{2}$ Department of Biostatistics, University of Leeds, \\ LS2 9JT, UK
}

Evidence exists that a low glycaemic index (GI) diet characterised by foods lower in refined starches, sugar and higher in fibre, particularly soluble fibre, may be associated with better health outcomes. ${ }^{(1)}$ According to a previous review higher glycaemic index (GI) diets increase fasting blood glucose and glycated proteins. ${ }^{(2)}$ The associations are currently unclear for other established markers of cardiovascular disease such as blood pressure and plasma lipids.

The aim of this study was to determine the effects of high glycaemic index (GI) or high glycaemic load (GL) diets and markers of cardiovascular disease including systolic and diastolic blood pressure, body weight, BMI, total cholesterol, LDL cholesterol, HDL cholesterol, triacylglycerol, fasting plasma glucose, plasma C-reactive protein, and non-esterified fatty acids (NEFAs) and energy intake in non-diseased populations.

A systematic literature review was carried out using appropriate search terms in Medline and several other databases to identify high quality randomised controlled trials of 6 weeks duration or more, published before December 2009 in English language. Meta-analysis was performed where a minimum of three studies were found for each health outcome. Studies measuring GI and GL were combined.

Data were extracted from 27 trials in which the glycaemic index or load of the diet had been manipulated and compared with lower index or load diets and cardio-metabolic outcomes. Summary pooled estimates obtained from random effects meta-analyses indicated that a high glycaemic index or high glycaemic load diet was associated with significant increases in total cholesterol $(0.13 \mathrm{mmol} / \mathrm{L}, 95 \% \mathrm{CI}$ 0.02 to $0.24 \mathrm{mmol} / \mathrm{L})$, LDL cholesterol $(0.14 \mathrm{mmol} / \mathrm{L}, 95 \% \mathrm{CI} 0.06$ to $0.22 \mathrm{mmol} / \mathrm{L})$ and diastolic blood pressure $(1.7 \mathrm{mmHg}, 95 \% \mathrm{CI} 0.0$ to $3.5 \mathrm{mmHg}$ ). There were no significant associations with high glycaemic index or glycaemic load diets in fasting blood glucose $(-0.03 \mathrm{mmol} / \mathrm{L}, 95 \% \mathrm{CI}-0.11$ to $0.05 \mathrm{mmol} / \mathrm{L})$, HDL cholesterol $(0 \mathrm{mmol} / \mathrm{L}, 95 \% \mathrm{CI}-0.06$ to $0.06 \mathrm{mmol} / \mathrm{L})$, triacylglycerol $(0.03 \mathrm{mmol} / \mathrm{L}, 95 \% \mathrm{CI}-0.07$ to $0.13 \mathrm{mmol} / \mathrm{L})$, total cholesterol to $\mathrm{HDL}$ ratio $(0.04,95 \% \mathrm{CI}-0.13$ to 0.22$)$, NEFAs $(0.01 \mathrm{mmol} / \mathrm{L}$, $95 \% \mathrm{CI}-0.05$ to $0.08 \mathrm{mmol} / \mathrm{L})$, systolic blood pressure $(0.72 \mathrm{mmHg}, 95 \% \mathrm{CI}-1.44$ to $2.88 \mathrm{mmHg}), \mathrm{C}$ reactive protein $(0.11 \mathrm{mg} / \mathrm{L}$, $95 \% \mathrm{CI}-0.50$ to $0.72 \mathrm{mg} / \mathrm{L})$, body weight $(0.08 \mathrm{~kg}, 95 \% \mathrm{CI}-0.96$ to $1.13 \mathrm{~kg})$ or fat mass $(0.56 \mathrm{~kg}, 95 \% \mathrm{CI}-0.63 \mathrm{to} 1.75 \mathrm{~kg})$.

Higher glycaemic diets were associated with a worsening of some markers of cardio-metabolic health but not others. More research is warranted to elucidate the underlying mechanisms behind these findings.

This work was funded by the Department of Health for England.

1. Jenkins DJ, Kendall CW, Augustin LS, Franceschi S, Hamidi M, Marchie A, et al. (2002) Glycemic index: overview of implications in health and disease. Am J Clin Nutr 76(1), 266S-73S

2. Livesey G, Taylor R, Hulshof T, Howlett J. (2008) Glycemic response and health-a systematic review and meta-analysis: relations between dietary glycemic properties and health outcomes. Am J Clin Nutr 87(1), 258S-68S. 